\title{
Host-specificity of Mycobiota in the Rhizosphere of Plants
}

\author{
S. Katoch, S. Sonia and L. Prasad* \\ Division of Plant Pathology, ICAR-Indian Agricultural Research Institute, \\ New Delhi, 110012, India \\ *Corresponding author
}

\begin{tabular}{l} 
Ke y w o r d s \\
$\begin{array}{l}\text { Rhizosphere, } \\
\text { Populations, Root } \\
\text { exudates, } \\
\text { Mycoflora }\end{array}$ \\
\hline Article Info \\
$\begin{array}{l}\text { Accepted: } \\
12 \text { October } 2020 \\
\text { Available Online: } \\
10 \text { November } 2020\end{array}$ \\
\hline
\end{tabular}

\section{A B S T R A C T}

In an expedition to find a solution against seed and soil borne infections, host-specific fungal flora assessment from the rhizosphere of rice, Sorghum, pigeonpea and urdbean was done. The rhizospheric soil of each crop was processed using serial dilution method. In cultivated soil (control), total 11 mycoflora viz. Aspergillus spp, A. terreus, A. niger, A. flavus, Penicillium spp., Fusarium oxysporum, Fusarium spp., Curvularia lunata, Rhizopus spp., Neurospara sitophila and Trichoderma spp. were found. However, the specific recruitment of rhizospheric mycoflora by the individual host was recorded which might be because of specific root exudates released by host. Highest mycoflora was associated with Sorghum i.e., $14.85 \%$ (20DAS) and $25.74 \%$ (40DAS) followed by rice and pigeonpea. Additionally, a progressive increase in mycoflora with the crop growth stage was also observed. The generated information could be utilized for sustaining agricultural production with the consideration of providing crop specific fungal consortia and healthy pesticide-free food.

\section{Introduction}

The close vicinity of plant roots is inhabited by a population of specific microbes depending upon the type of exudates (sugars, amino acids or many other compounds) released from the root surface and that region of microbe and plant interaction is known as rhizosphere (Berg and Smalla, 2009).
Rhizospheric soil is one of the richest sources of microbial community and these soils possess very huge diversity of both beneficial and pathogenic microbes. Different microbe's viz. bacteria, fungi, oomycetes, algae, viruses, nematodes, protists etc. are present in the rhizosphere. These microbiota species either have beneficial/ detrimental/ neutral or additive effects on plant growth and 
development (Mendes et al., 2013; Xiong et al., 2020). Plant roots releases various chemicals or compounds viz. exudates, metabolites or breakdown products into the rhizosphere soil to attract different microbes (Zhang et al., 2019). There are reports in which crop specific rhizospheric microbes have been reported like- in rice (Breidenbach et al., 2016), Sorghum and sunflower (Oberholster et al., 2018), pigeonpea (Jalander and Gachande 2018). Additionally, there exists report in which the effect of cultivar type, soil type and plant growth stage on the presence or absence of a particular microbe has reported in Sorghum (Schlemper et al., 2017). The rhizospheric microbes directly promote the plant growth by improving nutrient use efficiency and by activating the release of different growth promoting hormones. Along with this, these soil microbes also have direct (competition with pathogen) or indirect effect (activation of host defense mechanism) on the growth and development of pathogenic microbes (Nihorimbere et al., 2011). The use of these microbial species in the management of plant diseases has already kept pace but in future attempts could be made for the utilization of novel microbiota species over pesticides (Zuhaib et al., 2019). The identified microbial species could be efficiently used to tackle problems created by the use of chemical pesticides (Ciancio et al., 2019). Keeping in view, the less explored potential of flora present in the rhizosphere, present investigation was planned and executed. In this study, the mycoflora present in the rhizosphere of four crops viz. rice, Sorghum, pigeonpea and urdbean were identified under controlled environmental conditions with the aim to know the host-specificity of mycoflora and to enrich the specific groups of bioagents. These potential microbes will be helpful in finding out good alternative to sustain the crop yield without having chemical residues in food.

\section{Materials and Methods}

To assess the mycoflora from the rhizosphere of rice, Sorghum, pigeon pea and urdbean, the surface sterilized seeds of each plant species viz. Pusa Basmati-1 (rice), U.P. Chari-1 (Sorghum), Pant U19 (urdbean) and UPAS 120 (pigeon pea) were planted in pots filled with the soil collected from cultivated field. The experiment was conducted in two sets of conditions, in the first one- unsterilized soil was used while in second one- sterilized soil (autoclaved) was filled in the pots. The experiment was repeated twice under controlled environmental conditions and three replications of each crop were kept. Mycoflora count from each treatment was recorded at 20 and 40 days after sowing. The rhizospheric soil were taken from the vicinity of three plants of each crop while the remaining plants were taken out during the next observation to assess mycoflora association with plant growth stages as whether they are further changed in number or not. Additionally, soil samples were also taken from top $5 \mathrm{~cm}$ soil layer of each crop and control. The isolation of mycoflora was carried out using the serial dilution method in which $1 \mathrm{gm}$ soil was suspended in $10 \mathrm{ml}$ sterilized distilled water, mixed for 20 minutes then left for soil sedimentation. Further $1 \mathrm{ml}$ of suspension was taken out and mixed into $9 \mathrm{ml}$ sterilized water for further serial dilution. Later on the prepared suspension $(0.1 \mathrm{ml})$ was spread onto potato dextrose agar plates with the help of presterilized L shaped spreader and the inoculated plates were kept in an incubator at $25 \pm 2{ }^{\circ} \mathrm{C}$. Colony counting on inoculated plates was done after 48 hours of inoculation. All fungal colonies were isolated, purified, identified on the basis of morphology and microscopically and same were maintained at $4^{\circ} \mathrm{C}$ for further use. The identification of isolated fungi was made with the help of identification manuals (Ellis and Ellis, 1985), 
photographs available on the websites and other relevant material related to fungal systematics. Along with this, the cultural characteristics like colony colour, growth, type of conidia and mycelium etc. were also recorded and compared to already available literature.

\section{Results and Discussion}

The results of present study show significant differences for the presence or absence of a crop specific mycoflora in the samples collected from different crop rhizospheres. Different fungal species were isolated from the cultivated soil viz., Aspergillus spp., $A$. terreus, A. niger, A. flavus, Penicillium spp., Fusarium oxysporum, Fusarium spp., Curvularia lunata, Rhizopus spp., Neurospara sitophila, Trichoderma spp. etc. These fungal species were identified using identification manuals and photographs related to fungal systematics and found akin as per manuals. The morphological details of different isolated rhizospheric mycoflora are given in Table 1. Relative analysis between different rhizospheric mycoflora species indicates the association of maximum fungi with the Sorghum rhizospheric soil followed by rice and pigeon pea (Table 2). From the rice rhizosphere, only Fusarium and Rhizopus spp. were isolated after 20 days of sowing, while after 40 days Aspergillus spp., A. terreus, A. flavus and Penicillium spp. in addition to Fusarium and Rhizopus were isolated (Table 2). Overall, the number of fungal colony varies from 1 to 11. Maximum fungal colonies viz. A. flavus, Penicillium spp., Fusarium oxysporum, Rhizopus spp., Neurospara sitophila were isolated from the rhizosphere of Sorghum after 20 days of sowing whereas, during the last sampling (40DAS) one additional species i.e. A. terreus was also isolated. Likewise A. terreus and Rhizopus spp. were present in both pigeon pea and urdbean rhizosphere but Trichoderma spp. was present only in the rhizospheric soil taken from urdbean and that too in the last sampling (Table 2). Overall, Rhizopus spp. and $A$. terreus were the most prominent soil fungi isolated from the rhizosphere of all tested crops. Despite of presence in cultivated soil, A. niger and Curvularia lunata were not associated with the rhizospheric region of any crop. There was difference in the recruitment of mycoflora to the rhizospheric soil taken from a particular crop (Table 2). Additionally, the progressive increase of fungal association to individual host roots from first sampling to second one was also observed (Table 2). The present study indicated that each fungus has its specificity due to specific kind of exudates released by the roots of different crop plants. In addition to this, progression in the mycoflora population was also observed. This progression might be due to the release of specific exudates at different crop growth stages. In sterile soil, plant growth and development was poor (only visual observations, data not recorded) as compared to unsterilized soil which was due to the presence of microbial consortium in unsterile soils. This generated information could be utilized in plant health management i.e. we can apply the host specific beneficial microbial bioagents to avoid incompatibility among the rhizospheric fungi. The striking similarities with our study for the presence of some microbe's viz. Fusarium, Aspergillus, Rhizopus and Penicillium in rice rhizosphere were recorded in various studies conducted by many workers (Wang et al., 2016; Leewijit et al., 2016; Potshangbam et al., 2017). Along with this, the information on the evaluation of some of the isolated microbes for their effectiveness as bioagents against plant pathogens and on crop growth \& development has also been reported. In the sample from Sorghum and pigeon pea rhizosphere, Aspergillus spp., Curvularia spp., Fusarium, Rhizopus spp., Trichoderma spp., and Penicillium microbes were recorded in our 
study which is also supported by the observations of many workers (Balasubramanian and Rangaswami, 1978; Patil and Thakur, 2019; Srivastava et al., 2019). The observation of mycoflora progression with the growth stages of plants also collaborates with the previous studies in which root exudates released at different crop stages and type of cultivar had diversified effect on the population of rhizospheric microbes (Jalander and Gachande, 2018). This mycoflora variation in the rhizosphere of various crops might be because of antagonistic effect of one microbe on the other or because of various root/ seed exudates released by a particular crop (Balasubramanian and Rangaswami, 1978). This obtained information is a preliminary work in which we identified couple of rhizospheric fungi and in future these identified fungal species could be used in host-specific consortia development to improve soil properties and also sustainable crop cultivation.

Table.1 Morphological comparison of different fungal species isolated from the rhizosphere of rice, Sorghum, pigeon pea and urdbean

\begin{tabular}{|l|l|l|}
\hline Sr.No & Name of Microbe & Morphological characters \\
\hline $\mathbf{1}$ & Aspergillus sp. & Creamish white growth; round hyaline spores \\
\hline $\mathbf{2}$ & Aspergillus terreus & Tan or cinnamon brown colored colonies with white edge \\
\hline $\mathbf{3}$ & Aspergillus niger & Black colonies (initially white) appressed \\
\hline $\mathbf{4}$ & Aspergillus flavus & $\begin{array}{l}\text { Yellow-green spores on the upper surface and reddish-gold } \\
\text { pigmentation on the lower surface of Petri dish; Round spores }\end{array}$ \\
\hline $\mathbf{5}$ & Penicillium sp. & $\begin{array}{l}\text { Greyish green with white edge; powdery to velvety growth; } \\
\text { Globose to sub-globose conidia }\end{array}$ \\
\hline $\mathbf{6}$ & $\begin{array}{l}\text { Fusarium } \\
\text { oxysporum }\end{array}$ & Pinkish white cottony growth; hyaline macro- \& microconidia \\
\hline $\mathbf{7}$ & Fusarium sp. & Whitish colony with hyaline macro- \& microconidia \\
\hline $\mathbf{8}$ & Curvularia lunata & Greyish black colonies of fungus; conida 4 celled \\
\hline $\mathbf{9}$ & Rhizopus sp. & $\begin{array}{l}\text { Cottony, white coloured colony with black dot like sporangia; } \\
\text { Ellipsoid conidia }\end{array}$ \\
\hline $\mathbf{1 0}$ & $\begin{array}{l}\text { Neurospora } \\
\text { sitophila }\end{array}$ & Yellowish white growth; round macroconidia with 2-3 nuclei \\
\hline $\mathbf{1 1}$ & Trichoderma sp. & $\begin{array}{l}\text { Greenish white growth on the upper side of Petridish; transparent } \\
\text { \& round }\end{array}$ \\
\hline
\end{tabular}


Table.2 Determination of soil mycoflora collected from the rhizosphere of different crop plants

\begin{tabular}{|c|c|c|c|c|c|c|c|c|c|c|}
\hline \multirow{3}{*}{$\begin{array}{l}\text { Sr. } \\
\text { No. }\end{array}$} & \multirow{3}{*}{$\begin{array}{l}\text { Name of } \\
\text { Microbes }\end{array}$} & \multicolumn{8}{|c|}{ Name of crops } & \multirow{3}{*}{$\begin{array}{l}\text { Soil microbial } \\
\text { population before } \\
\text { seed sowing } \\
\text { (Control) }\end{array}$} \\
\hline & & \multicolumn{2}{|c|}{ Rice } & \multicolumn{2}{|c|}{ Sorghum } & \multicolumn{2}{|c|}{ Pigeon pea } & \multicolumn{2}{|c|}{ Urdbean } & \\
\hline & & $\begin{array}{c}20 \\
\text { DAS }^{*}\end{array}$ & $\begin{array}{c}40 \\
\text { DAS }\end{array}$ & $\begin{array}{c}20 \\
\text { DAS }\end{array}$ & $\begin{array}{l}40 \\
\text { DAS }\end{array}$ & $\begin{array}{c}20 \\
\text { DAS }\end{array}$ & $\begin{array}{c}40 \\
\text { DAS }\end{array}$ & $\begin{array}{c}20 \\
\text { DAS }\end{array}$ & $\begin{array}{l}40 \\
\text { DAS }\end{array}$ & \\
\hline 1 & $\begin{array}{c}\text { Aspergillus } \\
\text { spp. }\end{array}$ & - & $1(5)$ & - & - & - & - & - & - & $2(1.98)$ \\
\hline 2 & $\begin{array}{c}\text { Aspergillus } \\
\text { terreus }\end{array}$ & - & $\begin{array}{c}11 \\
(55.0)\end{array}$ & - & $\begin{array}{c}3 \\
(11.5)\end{array}$ & $\begin{array}{c}4 \\
(36.3)\end{array}$ & $\begin{array}{c}9 \\
(52.9)\end{array}$ & $\begin{array}{c}2 \\
(66.7)\end{array}$ & $\begin{array}{c}4 \\
(50.0)\end{array}$ & $27(26.7)$ \\
\hline 3 & $\begin{array}{l}\text { Aspergillus } \\
\text { niger }\end{array}$ & - & - & - & - & - & - & - & - & $1(0.99)$ \\
\hline 4 & $\begin{array}{l}\text { Aspergillus } \\
\text { flavus }\end{array}$ & - & $\begin{array}{c}1 \\
(5.0)\end{array}$ & $\begin{array}{c}5 \\
(33.3)\end{array}$ & $1(3.8)$ & $\begin{array}{c}3 \\
(27.3)\end{array}$ & $\begin{array}{c}3 \\
(17.65)\end{array}$ & - & - & $15(14.9)$ \\
\hline 5 & $\begin{array}{l}\text { Penicillium } \\
\text { spp. }\end{array}$ & - & $\begin{array}{c}1 \\
(5.0)\end{array}$ & $\begin{array}{c}3 \\
(20.0)\end{array}$ & $\begin{array}{c}12 \\
(46.2)\end{array}$ & $1(9.1)$ & $1(5.9)$ & - & - & $21(20.8)$ \\
\hline 6 & $\begin{array}{l}\text { Fusarium } \\
\text { oxysporum }\end{array}$ & - & - & $\begin{array}{c}1 \\
(6.7)\end{array}$ & $\begin{array}{c}4 \\
(15.4)\end{array}$ & $\begin{array}{c}2 \\
(18.2)\end{array}$ & $\begin{array}{c}3 \\
(17.65)\end{array}$ & - & - & $10(9.9)$ \\
\hline 7 & Fusarium spp. & $2(40.0)$ & $\begin{array}{c}3 \\
(15.0)\end{array}$ & - & - & - & - & - & - & $2(1.98)$ \\
\hline 8 & $\begin{array}{c}\text { Curvularia } \\
\text { lunata }\end{array}$ & - & - & - & - & - & - & - & - & $1(0.99)$ \\
\hline 9 & Rhizopus spp. & $3(60.0)$ & $\begin{array}{c}3 \\
(15.0)\end{array}$ & $\begin{array}{c}2 \\
(13.3)\end{array}$ & $2(7.7)$ & $1(9.1)$ & $1(5.9)$ & $1(33.3)$ & $\begin{array}{c}1 \\
(12.5)\end{array}$ & $15(14.9)$ \\
\hline 10 & $\begin{array}{l}\text { Neurospora } \\
\text { sitophila }\end{array}$ & - & - & $\begin{array}{c}4 \\
(26.7)\end{array}$ & $\begin{array}{c}4 \\
(15.4)\end{array}$ & - & - & - & - & $4(3.96)$ \\
\hline 11 & $\begin{array}{c}\text { Trichoderma } \\
\text { spp. }\end{array}$ & - & - & - & - & - & - & - & $\begin{array}{c}3 \\
(37.5)\end{array}$ & $3(2.9)$ \\
\hline \multicolumn{2}{|c|}{$\begin{array}{l}\text { Total soil fungi } \\
\text { Associated with } \\
\text { rhizosphere }\end{array}$} & 5 & 20 & 15 & 26 & 11 & 17 & 3 & 8 & $\begin{array}{c}101 \\
\text { (Total soil fungi) }\end{array}$ \\
\hline
\end{tabular}

* DAS: days after sowing; Dash symbol indicating No fungus associated with plant rhizosphere; Values in parethesis are percent microbial population within the sample; Values outside the parenthesis are individual fungal colonies.

\section{Acknowledgements}

The authors are grateful to Director, ICARIARI, New Delhi for providing research platform and facilities.

\section{References}

Balasubramanian, A., and Rangaswami, G. 1978. Influence of seed and root exudations on the rhizosphere effect in
Sorghum vulgare and Crotalaria juncea. Folia Microbiologica. 23(6): 481-488.

https://doi.org/10.1007/bf02885579.

Berg, G., and Smalla, K. 2009. Plant species and soil type cooperatively shape the structure and function of microbial communities in the rhizosphere. FEMS Microbiology Ecology. 68 (1): 1-13. https://doi.org/10.1111/j.15746941.2009.00654.x. 
Breidenbach, B., Pump, J., and Dumont, MG. 2016. Microbial community structure in the rhizosphere of rice plants. Frontiers in Microbiology. 6: 6-7. https://doi.org/10.3389/fmicb.2015.015 37.

Ciancio, A., Pieterse, C.M.J., and MercadoBlanco, J. 2019. Editorial: Harnessing useful rhizosphere microorganisms for pathogen and pest biocontrol-Second Edition. Frontiers in Microbiology. 10: 6-7. $\quad$ https://doi.org/10.3389/fmicb. 2019.01935 .

Ellis, M.B., and Ellis, J.P. 1985. Microfungi on Land Plants, Macmillan Pub, New York.

Jalander, V., and Gachande, B.D. 2018. Studies on quantitative analysis of rhizosphere and non-rhizosphere mycoflora at different stages of plant growth in different varieties of pigeon pea [Cajanus cajan (L.) Millspp.]. International Journal of Pure and Applied Bioscience. 6 (2): 357-363. doi: http://dx.doi.org/10.18782/23207051.6121.

Leewijit, T., Pongnak, W., Soytong, K., and Poeaim, S. 2016. Isolation of soil and endophytic fungi from rice (Oryza sativa L.). International Journal of Agricultural Technology 12 (7.2): 21912202.

Mendes, R., Garbeva, P., and Raaijmakers, J.M. 2013. The rhizosphere microbiome: significance of plant beneficial, plant pathogenic, and human pathogenic microorganisms. FEMS Microbiology Reviews. 37 (5): 634-663. https://doi.org/10.1111/15746976.12028.

Nihorimbere, V., Ongena, M., Smargiassi, M., and Thonart, P. 2011. Beneficial effect of the rhizosphere microbial community for plant growth and health. Biotechnology, Agronomy, Society and Environment. 15 (2): 327-337.
Oberholster, T., Vikram, S., Cowan, D., and Valverde, A. 2018. Key microbial taxa in the rhizosphere of Sorghum and sunflower grown in crop rotation. Science of the Total Environment. 624: 530-539. https://doi.org/10.1016/j.scitotenv.2017. 12.170 .

Patil, S.Y., and Thakur, V. 2019. Rhizosphere mycoflora from dry crop fields of Sorghum spp. (Jowar) in Dhule District (M.S. India). International Journal of Universal Science and Technology. 5: 176-180.

Potshangbam, M., Devi, S.I., Sahoo, D., and Strobel, G.A. 2017. Functional characterization of endophytic fungal community associated with Oryza sativa L. and Zea mays L. Frontiers in Microbiology. 8: 6-10. https://doi.org/10.3389/fmicb.2017.003 25.

Schlemper, T.R., Leite, M.F.A., Lucheta, A.R., Shimels, M., Bouwmeester, H.J. et al. 2017. Rhizobacterial community structure differences among sorghum cultivars in different growth stages and soils. FEMS Microbiology Ecology. 93 (8): 6-7. https://doi.org/10.1093/femsec/fix096.

Srivastava, M.P., Yadav, N., Kanaujjia, P., Awasthi, K., and Sharma, Y.K. 2019. Relationship between mycoflora and soil functionality in pigeon pea (Cajanus cajan L.) in some districts of Uttar Pradesh, India. International Journal of Plant and Environment. 5 (02): $117-123$. https://doi.org/10.18811/ijpen.v5i02.8.

Wang, W., Zhai, Y., Cao, L., Tan, H., and Zhang, R. 2016. Endophytic bacterial and fungal microbiota in sprouts, roots and stems of rice (Oryza sativa L.). Microbiological Research. 188-189. 1-8. https://doi.org/10.1016/j.micres.2016.04 
.009 .

Xiong, W., Song, Y., Yang, K., Gu, Y., Wei, Z., Kowalchuk, G.A., Xu, Y., Jousset, A., Shen, Q., and Geisen, S. 2020. Rhizosphere protists are key determinants of plant health. Microbiome. $8 \quad$ (1): 1-2. https://doi.org/10.1186/s40168-02000799-9.

Zhang, F., Xu, X., Huo, Y., and Xiao, Y. 2019. Trichoderma-inoculation and mowing synergistically altered soil available nutrients, rhizosphere chemical compounds and soil microbial community, potentially driving alfalfa growth. Frontiers in Microbiology. 9: 45. https://doi.org/10.3389/fmicb.2018. 03241.

Zuhaib, M., Ashraf, S., Musheer, N., and Ali, M. 2019. Role of rhizospheric microbes in the management of phytopathogens. In: Ansari, R., Mahmood, I., (eds) Plant Health Under Biotic Stress. Springer, Singapore. https://doi.org/10.1007/978981-13-6040-4_4.

\section{How to cite this article:}

Katoch, S., S. Sonia and Prasad, L. 2020. Host-specificity of Mycobiota in the Rhizosphere of Plants. Int.J.Curr.Microbiol.App.Sci. 9(11): 1903-1909.

doi: https://doi.org/10.20546/ijcmas.2020.911.225 